\title{
Proximate and mineral composition of industrialized biscuits
}

\author{
Maria Eliza Assis dos PASSOS ${ }^{1 \star}$, Carolina Ferraz Figueiredo MOREIRA ${ }^{1}$, Maria Teresa Bertoldo PACHECO ${ }^{2}$, \\ Iracema TAKASE ${ }^{3}$, Maria Lucia Mendes LOPES ${ }^{1}$, Vera Lucia VALENTE-MESQUITA ${ }^{1}$
}

\begin{abstract}
The aim of this study was to analyze the proximate and mineral composition of 21 types of biscuits. All biscuits showed high fat contents, significantly different $(P<0.05)$ from those described on the labels, except for three brands. Insoluble fiber fractions were predominant in the analyzed samples. Among the 21 biscuits analyzed, 16 showed food label values $20 \%$ higher than those allowed by law, according to RDC 360 , for fat, protein, total fiber, calcium, and sodium levels. This difference reached $273 \%$ for the sodium content. The calcium content was included only on the label of three samples analyzed, and the values described were significantly lower than those obtained analytically. Considering that biscuits are consumed by people of all age groups and of different socioeconomic levels, the results can contribute to the plans for health policies, such as surveillance of nutritional labeling, ensuring the reliability of the information provided by the food industry and enabling the identification of the relationship between dietary factors and the occurrence of non-transmissible chronic diseases.
\end{abstract}

Keywords: industrialized foods; food-composition databases; nutritional labels.

\section{Introduction}

Food composition databases (FCDBs) are essential tools for dietitians and other health professionals. FCDBs are used to assess the dietary status of patients and dietary intakes of population groups with defined demographic characteristics to plan and evaluate the dietary adequacy of meals and diets and to identify relationships between diet, health, and diseases according to the results of national, clinical, and epidemiologic studies (PENNINGTON, 2008). FCDBs must be constantly updated with the introduction of new food products. To avoid mistaken decisions or interpretations, FCDBs must be a high quality, reliable, up-to-date food composition databases and representative of the food consumed by the population (PENNINGTON, 2008; SICHERT-HELLERT et al., 2007).

Nutritional labeling, besides constituting an important instrument in the context of health promotion, aims to guarantee consumer access to information and help in the selection and acquisition of healthy foods. By identifying the nutrients present in foods, duly informed individuals have the necessary autonomy, liberty, and knowledge to make suitable food choices (BRASIL, 2004). Therefore, the dissemination of clear and correct information must be widely adopted and regulated by the appropriate governmental organization (SCAGLIUSI; MACHADO; TORRES, 2005).

In Brazil, the most important resolution of nutritional labeling is the RDC \# 360, which establishes the mandatory declaration of the contents of carbohydrate, protein, total fat, saturated fat, trans fat, dietary fiber, sodium, and energy value. Additionally, contents of vitamins and other minerals may optionally be declared, provided that each portion of food contains at least $5 \%$ of Dietary Reference Intake (DRI) (BRASIL, 2003). It is important to emphasize that despite the optional declaration of iron, calcium, and cholesterol, the levels of these nutrients are useful information for both consumers and health professionals (FERREIRA; LANFER-MARQUEZ, 2007). A $20 \%$ variability in the nutritional information on the label is acceptable with respect to the values obtained analytically (BRASIL, 2003). According to Dunbar (2010), an important aspect of regulations is safeguarding the health of consumers. Accordingly, it is of utmost importance for them that commercial food products are labeled accurately and unambiguously (DUNBAR, 2010).

The food market is constantly changing, leading to a growing diversity of available foods (SICHERT-HELLERT et al., 2007). Among them, bakery products, such as sweet or salty biscuits (commonly known as cookies or crackers, respectively) are food items regularly consumed by people of all social classes and age groups (TYAGI et al., 2007). Biscuits have become a traditional and significant food in many countries (MOHSEN et al., 2009; CONFORTI; LUPANO, 2004).

Based on the Family Budget Research project of 20022003 in Brazil, Levy-Costa et al., (2005) observed an increase of approximately $400 \%$ in biscuit consumption, compared to the consumption in the period of 1974-1975. Biscuits are products made mainly of flour, sugar, fats, and other ingredients,

\section{Received 8/8/2012}

Accepted 7/3/2013 (005796)

${ }^{1}$ Departamento de Nutrição Básica e Experimental, Centro de Ciências da Saúde, Instituto de Nutrição Josué de Castro, Universidade Federal do Rio de Janeiro - UFRJ,

Av. Brigadeiro Trompowisky, s/n, bloco J, $2^{\circ}$ andar, sala 16, CEP 21941-902, Rio de Janeiro, RJ, Brazil, e-mail: mariaelizapassos@hotmail.com

2 Centro de Química de Alimentos e Nutrição Aplicada, Secretaria da Agricultura, Instituto de Tecnologia de Alimentos - ITAL, Av. Brasil, 2880, Jardim Chapadão, CEP 13070-178, Campinas, SP, Brazil

${ }^{3}$ Departamento de Química Analítica, Instituto de Química, Universidade Federal do Rio de Janeiro - UFRJ, Av. Athos da Silveira Ramos, 149, Cidade Universitária, CEP 21941-909, Rio de Janeiro, RJ, Brazil

${ }^{*}$ Corresponding author 
which are used in lower amount and lower moisture content (PEREGO et al., 2007). The long shelf life of these products allows large production and wide distribution (TYAGI et al., 2007). Traditionally, biscuits are not considered to be a good source of minerals. However, recently, the biscuit industry has been enriching them with these micronutrients and including the information "mineral-enriched" on their nutritional labels.

Considering that the evaluation of individual and population nutrient and energy intake is a task that demands detailed and accurate information about the chemical composition of foods and that biscuits are habitually consumed by a great part of the population and there is a lack of data on the chemical composition of these products in FCDBs, the aim of this study was to analyze the content of moisture, ash, protein, total fat, total fiber and fractions, sodium, iron, cupper, zinc, calcium, magnesium, phosphorus, and potassium of commonly consumed biscuits in Brazil.

\section{Materials and methods}

\subsection{Selection of samples}

The selection of biscuits analyzed in the present study was based upon the conclusions reported on the study of Teixeira, Veiga and Sichieri (2007), whose protocol was approved by the Ethics Committee in Research of the Hospital University Clementino Fraga Filho of Federal University of Rio de Janeiro. In the present study, 539 questionnaires about nutritional habits were answered, out of which only the ones that mentioned the consumption of biscuits were included $(\mathrm{n}=488)$. The 21 most consumed varieties of biscuits composed our sample.

The biscuits were bought from several grocery stores in Rio de Janeiro at least 6 months prior to their expiring date. Twenty-one types of biscuits were selected, including sweet and salty ones. For each biscuit type, three different batches were purchased, and for each batch, three samples were purchased. The samples from each batch were homogenized into one sample that was analyzed in triplicate.

The samples were homogenized in an analytic micro-mill Retsch, mesh 0.50 , placed in nylon bags, which were sealed using a vacuum sealer (TecMaq, TM 250 Liquid, São Paulo, Brazil), identified, stored under vacuum, and frozen at $-22^{\circ} \mathrm{C}$ until analyses.

\subsection{Chemical composition}

Moisture content was determined by the gravimetric method with oven drying (Fabbe-Primer ${ }^{\circ}$ ) at $105^{\circ} \mathrm{C}$. Total fat was determined by the Soxhlet extraction method and protein content by the Kjeldahl total nitrogen method. Ash content was determined by carbonization and incineration of samples in a muffle furnace (EDGCON $\left.{ }^{\circledR} 1 \mathrm{P} 3000\right)$ at $550^{\circ} \mathrm{C}$ for 6 hours. Analyses were performed in triplicate for each batch of biscuits in accordance to the standard methods of Association of Official Analytical Chemists (ASSOCIATION..., 2005). The conversion factor for total nitrogen to protein of 5.75 was used (JONES, 1941; BRASIL, 2003).
Bearing in mind that the biscuits chosen for this study are not considered a source of fiber, a sub-sample $(25 \%)$ was used to determine the fiber content, which was processed in collaboration with Laboratory of Center for Food Chemistry and Applied Nutrition of Institute of Food Technology.

Dietary fiber was determined in duplicate in five different types of biscuits. The samples were previously dried and defatted. Total dietary fiber and soluble and insoluble fractions were determined by an enzymatic-gravimetric technique described by Prosky et al. (1992). The enzymes $\alpha$-amylase (Prozyn Industry and Commerce Ltda ${ }^{\circ}$ ) and amiloglucosidase alcalase (Novo Nordisk do Brasil Ltda ${ }^{\varpi}$ ) were used.

\subsection{Mineral analysis}

The samples were burned in a muffle furnace at $550^{\circ} \mathrm{C}$ for 6 hours, and the ashes were dissolved in concentrated hydrochloric acid (Merck). Iron, calcium, copper, magnesium, and zinc were determined by atomic-absorption spectrophotometry (PerkinElmer Model 3300). Sodium and potassium were determined by flame photometry (Micronal B260) and phosphorus by visible spectrophotometry (Femto 600s), via the ammonium phosphovanadomolybdate. The analyses were performed according to AOAC (ASSOCIATION..., 2005). The results were obtained after three readings of each triplicate and expressed in $\mathrm{g} / 100 \mathrm{~g}$.

All reagents used in the analysis were of analytical grade.

\subsection{Statistical analysis}

The data were submitted to analysis of variance (ANOVA), and the means of the treatments were compared statistically by the Tukey's test at $95 \%$ confidence level. The Student $t$-test, with a 95\% confidence level, was used for comparison between mean values obtained by analysis and those reported on the products labels. Statistical analysis was performed using a Microsoft Office Excel XP (Microsoft Corporation").

\section{Results and discussion}

Average moisture and ash contents of the evaluated biscuits are shown in Table 1. The average moisture content presented a great variation among the different classes (snack biscuits, sweets and crackers), from 1.7 to $5 \mathrm{~g} / 100 \mathrm{~g}$, as well as within the same class. It was similar to that described by Pareyt et al. (2009) in biscuits, which varied from 1.00 to $5.00 \%$. The highest moisture content value was observed in cheese snack biscuits (5 g/100 g of fresh product) and in chocolate biscuits (4.0\% of fresh product), for salty and sweet samples, respectively. Water is present in virtually all foods, and it is important for a number of chemical. Moisture determination is one of the most common tests in foods since the water content in foods has an important relationship between conservation and the chemical, physical and microbiological changes during the storage (SAMPAIO et al., 2009).

With respect to ash content, it was observed that the stuffed biscuit group was the one that showed the greatest variation, from 0.5 to $1.7 \mathrm{~g} / 100 \mathrm{~g}$. The strawberry wafer biscuit showed 
Table 1. Total moisture, ash, fat, and protein content of biscuits and difference between the content of fat and protein and that printed on nutritional labels.

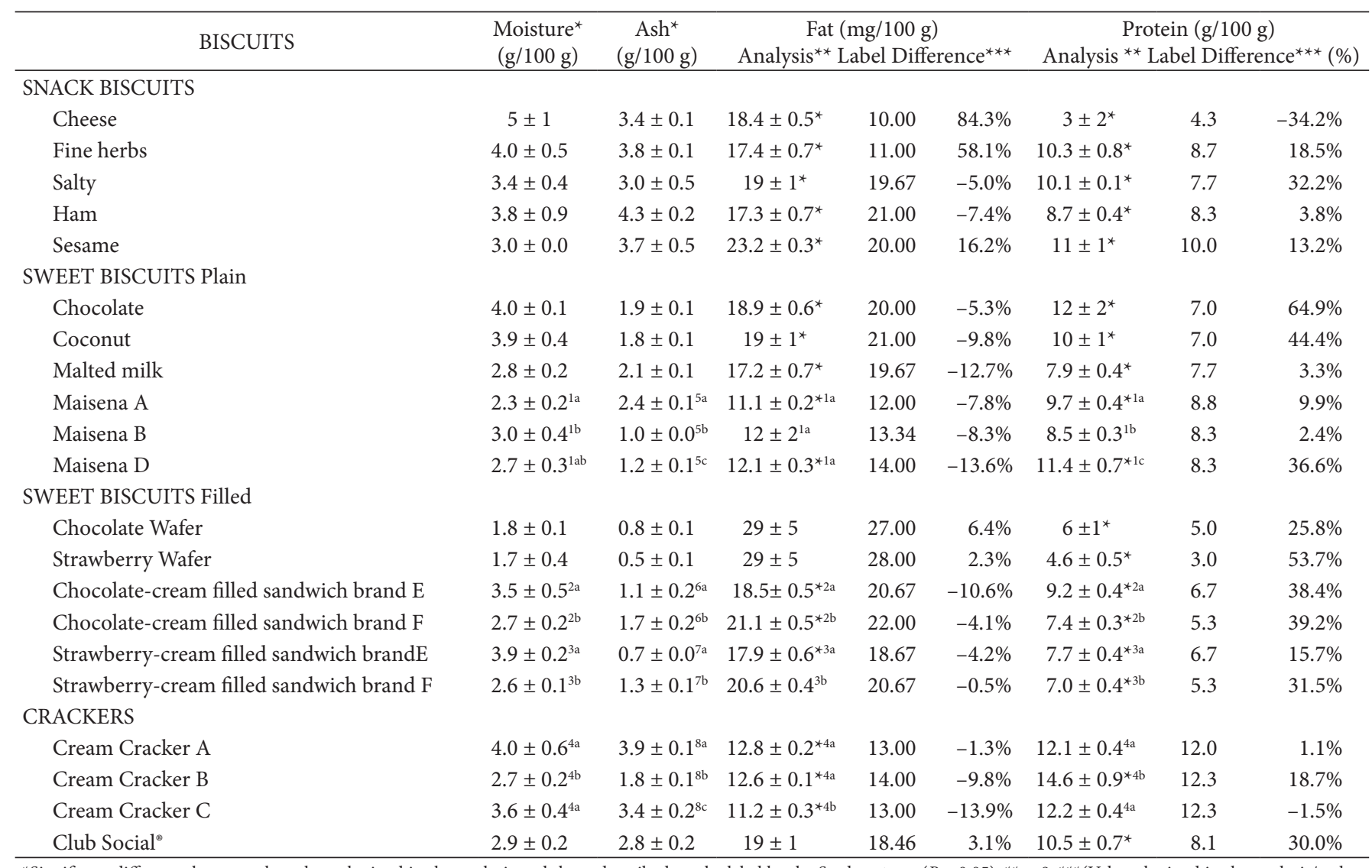

${ }^{\star}$ Significant difference between the values obtained in the analysis and those described on the label by the Student $t$ test $(P<0.05)$; ${ }^{* *} \mathrm{n}=9$; ${ }^{* * *}($ Value obtained in the analysis/ value described on the label $\times 100)-100$. Different capital letters following types of biscuits refer to different brands. Means followed by the same letters for each group with the same number did not show statistically significant differences by Tukey test $(P<0.05)$.

the smallest ash content, $0.5 \pm 0.1 \mathrm{~g} / 100 \mathrm{~g}$, while the ham biscuit showed the highest, $4.3 \pm 0.2 \mathrm{~g} / 100 \mathrm{~g}$.

The Brazilian Health Ministry Resolution \# 269 (BRASIL, 2005) establishes DRI for some minerals. For adults, the recommended daily values are $14 \mathrm{mg}$ for iron, $900 \mu \mathrm{g}$ for copper, $7 \mathrm{mg}$ for zinc, $260 \mathrm{mg}$ for magnesium, 1,000 $\mathrm{mg}$ for calcium, and $700 \mathrm{mg}$ for phosphorus (BRASIL, 2005). This legislation has not established a DRI for potassium. According to the Brazilian Legislation, foods containing at least $15 \%$ of DRI per 100 grams of a given mineral can be considered a mineral source (BRASIL, 1998). In this study, the DRI for adults will be considered in the results discussion.

Food processing may increase the sodium content in food products not only by adding salt (sodium chloride), but also by the addition of additives that contain this mineral in their formulation, which aims to modify properties such as texture and flavor besides prolonging their shelf-life (FERRARI; SOARES, 2003).

The average sodium content of the biscuits varied from $123.8 \pm 0.6 \mathrm{mg} \%$ (chocolate wafer) to $1483 \pm 17 \mathrm{mg} \%$ ham flavored biscuits (Table 2). The stuffed biscuit group had the lowest sodium content. Almost all biscuits, except for the cream cracker (brand A), showed significant difference $(P<0.05)$ between the analyses' results and the respective labels. For the chocolate biscuit, this difference reached 272.9\%.

The recommendation for sodium intake is 2.4 grams daily; therefore, salt intake should not exceed 6.0 grams per day (SOCIEDADE..., 2003). The consumption of $100 \mathrm{~g}$ of ham flavored biscuits, fine herbs, sesame, and salty snack biscuits, which have sodium content higher than $1.100 \mathrm{mg} \%$, reached approximately $50 \%$ of the recommended daily level of sodium intake (SOCIEDADE..., 2003).

The amount of sodium intake was estimated by considering the recommended portion described on each biscuit nutritional label of (Figure 1). It was observed that the consumption of only one serving of the ham flavored biscuits, for example, reached about $18 \%$ of the DRI of sodium. It is important to consider that the usual intake is greater than the serving on which the nutritional value on the labels is based. The differences in the sodium contents found between the analyses' results and labels confirm that the total sodium amount consumed can be underestimated, especially when it is based on information described on the labels of manufactured products.

This excessive sodium intake is particularly worrisome since sodium can lead to high blood pressure, which is an independent risk factor for cardiovascular disease, compromising life quality 
Table 2. Average ${ }^{\star}$ sodium content of biscuits and difference between these contents and those printed on nutritional labels.

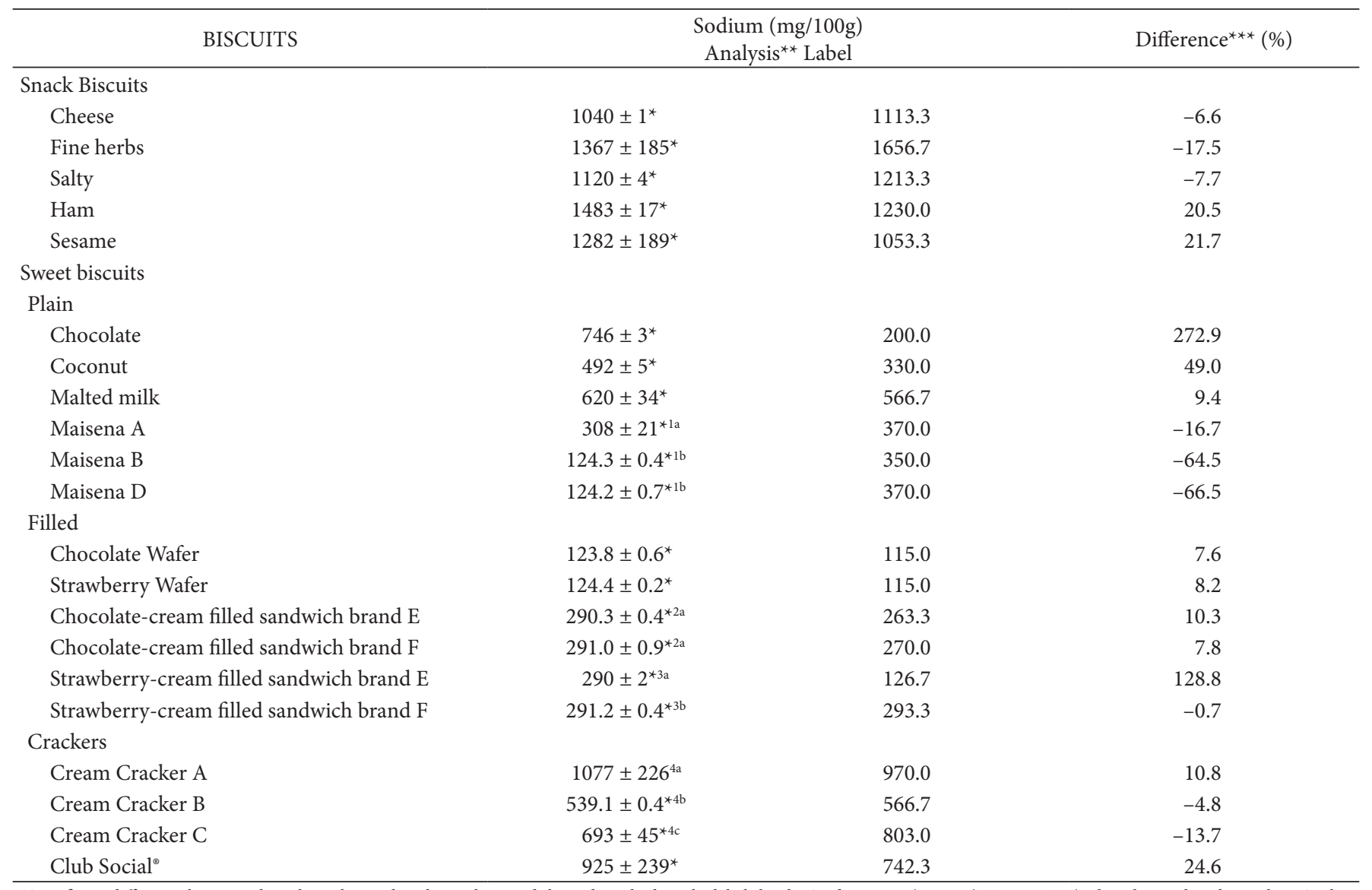

${ }^{*}$ Significant difference between the values obtained in the analysis and those described on the labels by the Student $t$ test $(P<0.05) ;{ }^{* *} \mathrm{n}=9$; ${ }^{* * *}($ Value obtained in the analysis $/$ value described on the label $\times 100)-100$. Different capital letters following types of biscuits refer to different brands. Means followed by the same letters for each group (identified by superscript numbers) with the same number did not show statistically significant differences by Tukey test $(P<0.05)$.

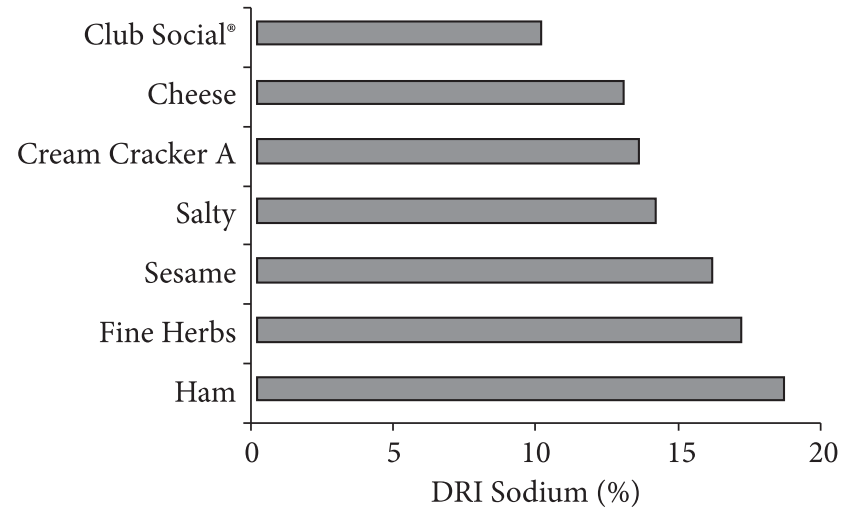

Figure 1. The percentage of DRI of recommended sodium intake for different types of biscuits.

resulting in high costs for health care (DIB; RIERA; FERRAZ, 2010).

People may be unaware that some of the main sources of salt in our diet are hidden in everyday food items and thus this may explain why many do not consider salt as a problem in their diet. Campaigns to improve education and awareness are necessary to raise consumers understanding the health risks of high salt consumption (GRIMES; RIDDELL; NOWSON, 2009). Reducing dietary sodium intake is a recognized method for treating and preventing hypertension for some individuals (CHAMPAGNE; LASTOR, 2009).

The average mineral contents are shown in Tables 3 and 4 . Different cream cracker biscuit brands showed both the smaller and the highest iron content, which were $1.4 \pm 0.3 \mathrm{mg} / 100 \mathrm{~g}$ (brand B) and $7 \pm 1 \mathrm{mg} / 100 \mathrm{~g}$ (brand C), respectively. This result highlights the variability in the chemical composition of different brands of the same biscuit type, which is a limiting factor for an accurate evaluation of nutrient intake for individuals or population.

There coexistence of multiple micronutrient deficiencies in developing countries has been increasingly recognized (OLIVARES et al., 2004). Iron deficiency is the most prevalent single nutritional deficiency in the world and is the main cause of anemia. In developing countries, the deficiency of this mineral is estimated to affect more than 3.5 billion people, and in Brazil, iron deficiency anemia remains a major problem (COZZOLINO, 2007; OLIVARES et al., 2004). Based on the current Brazilian legislation, almost all biscuits analyzed can be considered a source or iron, except for the cream cracker brand 
Table 3. Average* content of minerals in snack biscuits and crackers and percentage of DRI supplied by $100 \mathrm{~g}$ of biscuits.

\begin{tabular}{|c|c|c|c|c|c|c|c|}
\hline BISCUITS & $\begin{array}{l}\text { Iron (mg) } \\
(\% \mathrm{DRI})\end{array}$ & $\begin{array}{c}\text { Copper (mg) } \\
(\% \mathrm{DRI})\end{array}$ & $\begin{array}{l}\text { Zinc (mg) } \\
(\% \mathrm{DRI})\end{array}$ & $\begin{array}{l}\text { Calcium (mg) } \\
(\% \mathrm{DRI})\end{array}$ & $\begin{array}{c}\text { Magnesium (mg) } \\
(\% \mathrm{DRI})\end{array}$ & $\begin{array}{c}\text { Phosphorus (mg) } \\
\text { (\%DRI) }\end{array}$ & $\begin{array}{l}\text { Potassium (mg) } \\
\text { (DRI n.e.) }\end{array}$ \\
\hline Club Social $^{\circ}$ & $\begin{array}{c}4 \pm 2 \\
(28.6)\end{array}$ & $\begin{array}{c}0.3 \pm 0.1 \\
(30.0)\end{array}$ & $\begin{array}{c}0.8 \pm 0.1 \\
(11.3)\end{array}$ & $\begin{array}{c}231 \pm 25 \\
(23.1)\end{array}$ & $\begin{array}{l}28 \pm 4 \\
(10.7)\end{array}$ & $\begin{array}{c}386 \pm 61 \\
(55.2)\end{array}$ & $177 \pm 54$ \\
\hline Cream Cracker A & $\begin{array}{l}4.8 \pm 0.7 \\
(34.4)\end{array}$ & $\begin{array}{c}1.1 \pm 0.4 \\
(124.4)\end{array}$ & $\begin{array}{c}1.1 \pm 0.1 \\
(15.3)\end{array}$ & $\begin{array}{c}478 \pm 106 \\
\quad(47.8)\end{array}$ & $\begin{array}{l}36 \pm 7 \\
(13.7)\end{array}$ & $\begin{array}{c}168 \pm 45 \\
(24.1)\end{array}$ & $460 \pm 74$ \\
\hline Cream Cracker B & $\begin{array}{l}1.4 \pm 0.3 \\
(9.8)\end{array}$ & $\begin{array}{c}0.9 \pm 0.2 \\
(102.2)\end{array}$ & $\begin{array}{c}1.0 \pm 0.1 \\
(14.3)\end{array}$ & $\begin{array}{c}28 \pm 13 \\
(2.8)\end{array}$ & $\begin{array}{c}23 \pm 4 \\
(8.8)\end{array}$ & $\begin{array}{c}349 \pm 156 \\
(49.8)\end{array}$ & $124.4 \pm 0.3$ \\
\hline Cream Cracker C & $\begin{array}{l}7 \pm 1 \\
(52.6)\end{array}$ & $\begin{array}{l}0.7 \pm 0.1 \\
(75.6)\end{array}$ & $\begin{array}{c}1.2 \pm 0.3 \\
(17.6)\end{array}$ & $\begin{array}{c}293 \pm 61 \\
(29.3)\end{array}$ & $\begin{array}{c}27 \pm 11 \\
(10.5)\end{array}$ & $\begin{array}{c}193 \pm 15 \\
(27.5)\end{array}$ & $537 \pm 111$ \\
\hline Fine herbs & $\begin{array}{l}3 \pm 1 \\
(22.8)\end{array}$ & $\begin{array}{l}0.4 \pm 0.1 \\
(43.3)\end{array}$ & $\begin{array}{c}1.0 \pm 0.1 \\
(14.0)\end{array}$ & $\begin{array}{l}211 \pm 11 \\
(21.1)\end{array}$ & $\begin{array}{l}44 \pm 4 \\
(16.9)\end{array}$ & $\begin{array}{c}313 \pm 11 \\
(44.6)\end{array}$ & $264 \pm 30$ \\
\hline Sesame & $\begin{array}{l}4.9 \pm 0.7 \\
(35.0)\end{array}$ & $\begin{array}{l}0.4 \pm 0.1 \\
(46.7)\end{array}$ & $\begin{array}{c}1.4 \pm 0.4 \\
(19.6)\end{array}$ & $\begin{array}{c}200 \pm 48 \\
(20.0)\end{array}$ & $\begin{array}{c}58 \pm 15 \\
(22.4)\end{array}$ & $\begin{array}{c}250 \pm 49 \\
(35.7)\end{array}$ & $275 \pm 60$ \\
\hline Ham & $\begin{array}{l}4 \pm 1 \\
(26.1)\end{array}$ & $\begin{array}{l}0.3 \pm 0.1 \\
(27.8)\end{array}$ & $\begin{array}{l}0.9 \pm 0.1 \\
(12.3)\end{array}$ & $\begin{array}{c}202 \pm 23 \\
(20.2)\end{array}$ & $\begin{array}{l}68 \pm 7 \\
(26.2)\end{array}$ & $\begin{array}{c}353 \pm 89 \\
(50.4)\end{array}$ & $168 \pm 18$ \\
\hline Cheese & $\begin{array}{l}2.7 \pm 0.4 \\
(19.1)\end{array}$ & $\begin{array}{l}0.4 \pm 0.0 \\
(38.9)\end{array}$ & $\begin{array}{c}1.4 \pm 0.1 \\
(20.0)\end{array}$ & $\begin{array}{l}253.8 \pm 0.4 \\
\quad(25.4)\end{array}$ & $\begin{array}{l}55 \pm 3 \\
(21.2)\end{array}$ & $\begin{array}{c}328 \pm 19 \\
(46.8)\end{array}$ & $624 \pm 59$ \\
\hline Salty & $\begin{array}{l}3.0 \pm 0.5 \\
(21.5) \\
\end{array}$ & $\begin{array}{c}0.2 \pm 0.0 \\
(24.4) \\
\end{array}$ & $\begin{array}{c}0.9 \pm 0.1 \\
(13.1) \\
\end{array}$ & $\begin{array}{c}199 \pm 15 \\
(19.9) \\
\end{array}$ & $\begin{array}{l}39 \pm 9 \\
(15.1) \\
\end{array}$ & $\begin{array}{c}288 \pm 32 \\
(41.1) \\
\end{array}$ & $154 \pm 11$ \\
\hline
\end{tabular}

${ }^{*}$ Average of nine determinations. DRI = Dietary Reference Intake (BRASIL, 2005). (DRI n.e.) = DRI not established (BRASIL, 2005). Different capital letters following different types of biscuits refer to different brands.

Table 4. Average* mineral contents in different types of sweet biscuits and percentage of DRI supplied by $100 \mathrm{~g}$ of biscuits.

\begin{tabular}{|c|c|c|c|c|c|c|c|}
\hline BISCUITS & $\begin{array}{l}\text { Iron (mg) } \\
\text { (\%DRI) }\end{array}$ & $\begin{array}{c}\text { Copper (mg) } \\
(\% \mathrm{DRI})\end{array}$ & $\begin{array}{l}\text { Zinc (mg) } \\
\text { (\%DRI) }\end{array}$ & $\begin{array}{l}\text { Calcium (mg) } \\
(\% \mathrm{DRI})\end{array}$ & $\begin{array}{c}\text { Magnesium (mg) } \\
(\% \mathrm{DRI})\end{array}$ & $\begin{array}{c}\text { Phosphorus (mg) } \\
\text { (\%DRI) }\end{array}$ & $\begin{array}{l}\text { Potassium (mg) } \\
\text { (DRI n.e.) }\end{array}$ \\
\hline Chocolate & $\begin{array}{l}7 \pm 2 \\
(47.4)\end{array}$ & $\begin{array}{c}0.4 \pm 0.1 \\
(48.9)\end{array}$ & $\begin{array}{c}1.4 \pm 0.2 \\
(19.7)\end{array}$ & $\begin{array}{c}70 \pm 12 \\
(7.0)\end{array}$ & $\begin{array}{l}62 \pm 8 \\
(23.8)\end{array}$ & $\begin{array}{c}241 \pm 43 \\
(34.4)\end{array}$ & $463 \pm 76$ \\
\hline Coconut & $\begin{array}{c}4.8 \pm 0.4 \\
(34.5)\end{array}$ & $\begin{array}{c}0.3 \pm 0.1 \\
(37.8)\end{array}$ & $\begin{array}{l}1.1 \pm 0.1 \\
(15.0)\end{array}$ & $\begin{array}{c}38 \pm 5 \\
(3.8)\end{array}$ & $\begin{array}{l}48 \pm 3 \\
(18.6)\end{array}$ & $\begin{array}{c}301 \pm 15 \\
(42.94)\end{array}$ & $304 \pm 34$ \\
\hline Malted milk & $\begin{array}{c}2.9 \pm 0.7 \\
(20.4)\end{array}$ & $\begin{array}{l}0.2 \pm 0.0 \\
(23.3)\end{array}$ & $\begin{array}{l}0.8 \pm 0.1 \\
(11.9)\end{array}$ & $\begin{array}{c}142 \pm 6 \\
(14.2)\end{array}$ & $\begin{array}{l}36 \pm 2 \\
(14.0)\end{array}$ & $\begin{array}{c}269 \pm 22 \\
(38.4)\end{array}$ & $241 \pm 26$ \\
\hline Maisena A & $\begin{array}{c}6 \pm 2 \\
(43.2)\end{array}$ & $\begin{array}{c}0.4 \pm 0.1 \\
(44.4)\end{array}$ & $\begin{array}{c}1.2 \pm 0.1 \\
(16.6)\end{array}$ & $\begin{array}{c}829 \pm 106 \\
(82.9)\end{array}$ & $\begin{array}{l}61 \pm 8 \\
(23.5)\end{array}$ & $\begin{array}{c}165 \pm 20 \\
(23.6)\end{array}$ & $419 \pm 43$ \\
\hline Maisena B & $\begin{array}{c}2.7 \pm 0.9 \\
(19.1)\end{array}$ & $\begin{array}{c}0.4 \pm 0.1 \\
(44.4)\end{array}$ & $\begin{array}{l}0.9 \pm 0.0 \\
(12.3)\end{array}$ & $\begin{array}{c}56 \pm 14 \\
(5.6)\end{array}$ & $\begin{array}{l}45 \pm 3 \\
(17.4)\end{array}$ & $\begin{array}{c}151 \pm 20 \\
(21.5)\end{array}$ & $253 \pm 84$ \\
\hline Maisena D & $\begin{array}{l}3.7 \pm 0.7 \\
(26.4)\end{array}$ & $\begin{array}{l}0.3 \pm 0.1 \\
(36.7)\end{array}$ & $\begin{array}{l}0.9 \pm 0.2 \\
(13.1)\end{array}$ & $\begin{array}{c}77 \pm 12 \\
(7.7)\end{array}$ & $\begin{array}{l}45 \pm 7 \\
(17.5)\end{array}$ & $\begin{array}{c}157 \pm 24 \\
(22.4)\end{array}$ & $245 \pm 109$ \\
\hline $\begin{array}{l}\text { Chocolate-cream filled } \\
\text { sandwich brand E }\end{array}$ & $\begin{array}{c}3.1 \pm 0.4 \\
(22.4)\end{array}$ & $\begin{array}{l}0.5 \pm 0.1 \\
(52.2)\end{array}$ & $\begin{array}{c}1.0 \pm 0.1 \\
(14.0)\end{array}$ & $\begin{array}{c}50 \pm 10 \\
(5.0)\end{array}$ & $\begin{array}{l}62 \pm 3 \\
(23.8)\end{array}$ & $\begin{array}{l}143 \pm 17 \\
(20.5)\end{array}$ & $68 \pm 56$ \\
\hline $\begin{array}{l}\text { Chocolate-cream filled } \\
\text { sandwich brand } \mathrm{F}\end{array}$ & $\begin{array}{c}3.3 \pm 0.7 \\
(23.4)\end{array}$ & $\begin{array}{c}0.3 \pm 0.1 \\
(33.3)\end{array}$ & $\begin{array}{l}0.7 \pm 0.1 \\
(10.4)\end{array}$ & $\begin{array}{c}238 \pm 9 \\
(23.8)\end{array}$ & $\begin{array}{c}48 \pm 12 \\
(18.4)\end{array}$ & $\begin{array}{c}199 \pm 20 \\
(28.4)\end{array}$ & $475 \pm 222$ \\
\hline $\begin{array}{l}\text { Strawberry-cream filled } \\
\text { sandwich brand E }\end{array}$ & $\begin{array}{l}1.7 \pm 0.2 \\
(11.8)\end{array}$ & $\begin{array}{c}0.2 \pm 0.1 \\
(22.2)\end{array}$ & $\begin{array}{l}0.6 \pm 0.0 \\
\quad(9.1)\end{array}$ & $\begin{array}{c}37 \pm 18 \\
(3.7)\end{array}$ & $\begin{array}{l}34 \pm 3 \\
(13.2)\end{array}$ & $\begin{array}{l}70 \pm 3 \\
(10.0)\end{array}$ & $124 \pm 59$ \\
\hline $\begin{array}{l}\text { Strawberry-cream filled } \\
\text { sandwich brand F }\end{array}$ & $\begin{array}{l}4 \pm 1 \\
(28.7)\end{array}$ & $\begin{array}{c}0.4 \pm 0.1 \\
(44.4)\end{array}$ & $\begin{array}{l}0.8 \pm 0.1 \\
(12.0)\end{array}$ & $\begin{array}{c}281 \pm 49 \\
(28.1)\end{array}$ & $\begin{array}{l}54 \pm 8 \\
(23.6)\end{array}$ & $\begin{array}{c}192 \pm 11 \\
(27.5)\end{array}$ & $421 \pm 172$ \\
\hline Chocolate Wafer & $\begin{array}{c}3.5 \pm 0.9 \\
(25.1)\end{array}$ & $\begin{array}{c}0.3 \pm 0.1 \\
(36.7)\end{array}$ & $\begin{array}{l}0.6 \pm 0.0 \\
(8.29)\end{array}$ & $\begin{array}{c}49 \pm 12 \\
(4.9)\end{array}$ & $\begin{array}{l}43 \pm 4 \\
(16.7)\end{array}$ & $\begin{array}{c}109 \pm 18 \\
(15.6)\end{array}$ & $334 \pm 83$ \\
\hline Strawberry Wafer & $\begin{array}{l}1.9 \pm 0.4 \\
(13.6)\end{array}$ & $\begin{array}{l}0.1 \pm 0.0 \\
(15.6)\end{array}$ & $\begin{array}{c}0.3 \pm 0.1 \\
(4.1)\end{array}$ & $\begin{array}{c}49 \pm 19 \\
(4.8)\end{array}$ & $\begin{array}{c}19 \pm 1 \\
(7.3)\end{array}$ & $\begin{array}{l}78 \pm 8 \\
(11.2)\end{array}$ & $336 \pm 84$ \\
\hline
\end{tabular}

${ }^{\star}$ Average of nine determinations. DRI = Dietary Reference Intake (BRASIL, 2005). (DRI n.e.) = DRI not established (BRASIL, 2005). Different capital letters following different types of biscuits refer to different brands.

B, strawberry cream-filled sandwich biscuit brand E, and the strawberry wafer.

Food composition tables available in Brazil usually do not present data on copper content or, in some cases, they include only for a few types of foods (FERREIRA; GOMES; CHAVES,
2005). All the biscuits analyzed can be considered copper sources since their contents were greater than $15 \%$ of the DRI of this mineral. The cream cracker biscuits brands A and B showed high levels of copper; however, the required levels of copper where toxicity can occur are not well established. The amount normally 
ingested in food and water is relatively low, and most humans and animals are able to control excessive amounts of copper in the body by either decreased absorption or increased excretion (GAETKE; CHOW, 2003). An extremely large amount of orally ingested copper $(0.07 \mathrm{mg} / \mathrm{kg}$ per day) has been associated with adverse gastrointestinal effects (SHILS et al., 2003).

This amount could be achieved by a person of $70 \mathrm{~kg}$ by consuming approximately $450 \mathrm{~g}$ of cream cracker biscuits (brand A). Ferreira, Gomes and Chaves (2005) found $0.14 \mathrm{mg} / 100 \mathrm{~g}$ of copper in corn starch biscuits (Maizena ${ }^{\circ}$ ) and $0.21 \mathrm{mg} / 100 \mathrm{~g}$ in cream crackers. These values are three to five times lower than those found in the present study. The variations observed in the copper levels may be due to raw material since the method for the determination of this mineral was similar in both studies.

Campos-Vega, Loarca-Pina and Oomah (2010) observed that there is a direct correlation between the dietary copper and zinc ratio and the incidence of cardiovascular disease. Zinc deficiency in humans is recognized as a public health problem of global proportions (RAMÍREZ-CÁRDENAS et al., 2010). The highest zinc content was found in cheese biscuits $(1.4 \mathrm{mg} / 100 \mathrm{~g})$ and the lowest in strawberry wafer biscuits $(0.3 \mathrm{mg} / 100 \mathrm{~g})$. The copper, iron, and zinc contents reported in a Chilean study by Olivares et al. (2004) for the cream-filled chocolate sandwich biscuits were lower than those found for this type of biscuits in the present study.

Calcium consumption is generally very low in most populations considering the recommended values (COZZOLINO, 2007). In the present study, calcium content was cited on the labels only for the cream-filled strawberry and chocolate sandwich biscuits (brand F) and Club Social ${ }^{\circ}$ biscuits. The contents of this mineral were significantly higher than those reported on the labels of these three samples $(P<0.05)$. The Maizena ${ }^{\oplus}$ biscuit (brand A) showed the highest calcium content $(829 \mathrm{mg} / 100 \mathrm{~g})$, reaching approximately $83 \%$ of DRI. Calcium content in the other samples, as well as the contents of other minerals studied could not be compared to the product labels since they are not compulsory items on nutritional labeling.

Magnesium is present in almost all foods; consequently, a varied diet should provide the RDA for magnesium (JODRALSEGADO et al., 2003). Nevertheless, sometimes the diet in developed countries does not supply the necessary amount of magnesium due to the frequent consumption of processed food such as biscuits. The amount of magnesium found in ham flavored biscuits was the highest, representing $26 \%$ of DRI, and the lowest was found in the strawberry wafer biscuit, reaching only $7.25 \%$ of DRI.

Phosphorus is an important element in every cell of the body because it is part of cell membranes and bone. With the exception of strawberry cream-filled sandwich biscuit brand $\mathrm{E}$ and strawberry wafer biscuits, all the others showed a phosphorus content higher than 15\% of DRI, and therefore they are considered as sources of this mineral.

The potassium content found in the cheese biscuit $(624 \mathrm{mg} / 100 \mathrm{~g})$ was nine times higher than that found in chocolate cream-filled sandwich biscuit brand E (68 mg/100 g), showing the great variability of this mineral content in the different types of the biscuits studied. This difference may be associated with the additives used in the production of biscuits. According to Sherman and Mehta (2009), the impact of the additives on the dietary potassium is still largely unrecognized in the literature. Hyperkalemia is a significant cause of mortality in chronic kidney disease patients. In these cases, a long-term alternative is to include the potassium content of foods on the nutrition label.

All biscuits analyzed showed significantly high levels of fat (Table 1), which explains the why this kind of food is so high in calories. The samples with both the highest $(29 \mathrm{~g} / 100 \mathrm{~g}$ for chocolate and strawberry wafer biscuit) and the lowest $\left(11.1 \mathrm{~g} / 100 \mathrm{~g}\right.$ for Maizena ${ }^{\circledR}$ biscuit brand A) average contents of total fat were among the sweet biscuits. Menezes, Giuntini and Lajolo (2003), in a study based on a different FCDB, reported similar fat content for chocolate wafer biscuits (26.26\%).

The average fat contents were significantly different from those described on the corresponding labels, except for three biscuit brands. However, according to the RDC \# 360 (BRASIL, 2003 ), which states that a variation of $\pm 20 \%$ is the maximum acceptable deviation from the values presented on the labels, only the cheese snack biscuits (84.3\%) and the fine herb biscuits (58.1\%) biscuits were not in compliance with the Brazilian legislation (Table 1). This large difference may be related to the inevitable varying composition of the raw materials, the different methods of analysis, and also because, sometimes, information in the FCDB of other countries' can be used instead of that from the food's country of origin, which would be more accurate.

Lobanco et al. (2009), studying Brazilian food products, found that all of the sandwich and wafer biscuit samples evaluated were compliant with the legislation previously mentioned; Kus et al. (2011) found the same results in samples of infant formulas.

Fat consumption estimate is essential to plan public health actions. Considering that fat is the nutrient that provides the major caloric value, significant mistakes in total energy consumption estimate can occur, especially when the difference between the analytically obtained content and the value presented on the labels is great. Consumption estimate mistakes of this magnitude can result in health risk, mainly for individuals that require dietary management for weight loss, hyperlipidemias, diseases related with fat metabolism and others.

Although the levels of saturated and trans fat acids were not determined in this study, it is important to know the fatty acid profile of foods since a high intake of saturated fat contributes to the development of coronary heart disease, and trans fatty acids have also been associated with adverse effects, such as raising low density lipoprotein cholesterol (LDL) and lowering high density lipoprotein cholesterol (HDL) (MARTIN et al., 2005; TAVELLA et al., 2000).

Among the biscuits studied ( $\mathrm{n}=21), 11$ showed differences between the average protein contents determined analytically and the values described on the labels greater than those allowed by Brazilian legislation, reaching a maximum of $64.9 \%$ (Table 1 ). This difference can be harmful for people that need protein 
Table 5. Soluble, insoluble, and total fiber contents in biscuits and difference between these contents and those printed on nutritional labels.

\begin{tabular}{lccccc}
\hline \multicolumn{1}{c}{ BISCUITS } & $\begin{array}{c}\text { Soluble fiber } \\
\text { Analysis }\end{array}{ }^{*}(\mathrm{~g} / 100 \mathrm{~g})$ & $\begin{array}{c}\text { Insoluble fiber } \\
\text { Analysis }^{* *}(\mathrm{~g} / 100 \mathrm{~g})\end{array}$ & \multicolumn{3}{c}{ Total fiber $(\mathrm{g} / 100 \mathrm{~g})$} \\
\cline { 4 - 6 } Cream Cracker A & 1.32 & 0.89 & 2.21 & 2.60 & $-15.0 \%$ \\
Fine herbs & 0.09 & 1.07 & $1.16^{*}$ & 3.66 & $-68.3 \%$ \\
Sesame & 0.10 & 1.54 & $1.64^{*}$ & 4.00 & $-59.0 \%$ \\
Maisena B & 0.29 & 0.70 & $0.99^{*}$ & 0.00 & - \\
Chocolate-cream filled sandwich brand F & 0.11 & 0.58 & $0.69^{*}$ & 2.33 & $-70.4 \%$ \\
\hline
\end{tabular}

${ }^{*}$ Significant difference between the values obtained by analysis and those described on the label by the Student $t$ test $(\mathrm{P}<0.05)$. ${ }^{* *}$ Average of two determinations. ${ }^{* *}($ Value obtained in the analysis / value described on the label $\mathrm{x}$ 100) - 100. Different capital letters following types of biscuits refer to different brands.

control, for example people with kidney diseases. Lobanco et al. (2009) found non-compliance with the current legislation (BRASIL, 2003) in $10 \%$ of sandwich biscuit samples and $20 \%$ of wafer biscuits when comparing the laboratory analysis with the data described on the labels. In the present study, the levels of protein ranged from $3 \mathrm{~g} / 100 \mathrm{~g}$ in the cheese snack to $14.6 \mathrm{~g} / 100 \mathrm{~g}$ for cream cracker brand $\mathrm{B}$, which differed from those described by Rodrigues et al. (2007) that varied from $5.7 \mathrm{~g} / 100 \mathrm{~g}$ to $10.0 \mathrm{~g} / 100 \mathrm{~g}$ among four types of industrialized biscuits.

Biscuits have high levels of carbohydrates since they are mainly made of cereals and some of them have sugar added. The average carbohydrate contents varied from $56.80 \mathrm{~g} / 100 \mathrm{~g}$ to $74.61 \mathrm{~g} / 100 \mathrm{~g}$. The total carbohydrate of the biscuits were different from those described on the labels, probably due to the fact that they were calculated by difference (100 - total grams of moisture, protein, fat and ash). However, these variations were within the limits allowed by the Brazilian legislation.

The importance of fiber intake is largely due to its physiological effects that have benefic health implications (TOSH; YADA, 2010). Dietary fiber presence in food is of great interest for health (MENEZES et al., 2009; LEE et al., 2008). In Brazil, there is little information available about the different fiber fractions in foodstuffs and the biological availability of fiber consumed. The average soluble, insoluble, and total fiber contents of the five biscuit samples analyzed are described in Table 5. In addition to the total fiber content of a food product, it is essential to know its water solubility since the physiological effects of soluble and insoluble fiber are different. The reduction of blood cholesterol and glycemia are related to the consumption of soluble fiber (THEUWISSEN; MENSINK, 2008), while insoluble fibers can reduce the risk of developing diabetes mellitus (ISKEN et al., 2010), are hypocholesterolemic, and have beneficial effects on intestinal health (HSU; LIN; CHAU, 2009).

In the present study, the total fiber content of the biscuits studied differed from the labels' information, except for cream cracker samples, brand A. In a study on sandwich and wafer biscuits, the percentage of non-compliant samples with the $20 \%$ tolerance limit of RDC 360 (BRASIL, 2003) was 36\% and 6\%, respectively (LOBANCO et al., 2009). Lee et al. (2008) found a value of $2.52 \mathrm{~g} / 100 \mathrm{~g}$ of total fiber in cream crackers, which is similar to the value found in the present study for cream cracker brand A. Although this information is of great importance, biscuit labels do not list soluble or insoluble fiber fractions, they list only the total fiber content.
Menezes, Giuntini and Lajolo (2003), investigating different types of sweet biscuits based on FCDB data, reported differences in their composition, mainly because they have different formulations, reinforcing the importance of specific composition information for each type of biscuit. Additionally, it has been recognized that the comparison with FCDBs is hampered by the fact that most of these databases are international data compilations and do not reflect the composition of food produced in Brazil; furthermore they are inaccurate in terms of biscuit identification and description and do not report several minerals.

Food composition variability can be a reflection of inherent (genetic), environmental (climate, temperature, and soil type), processing (cooking and preservation method), and analytical factors (PENNINGTON, 2008; MENEZES; GIUNTINI; LAJOLO, 2003). In the present study, the differences found between the actual content of nutrients and the values described on biscuit labels highlight the importance of the adoption of careful analytical procedures. These include detailed food identification and quality control of the analytical methods thus ensuring accurate information. Brazilian legislation accepts a variation of $\pm 20 \%$ between labels described values and those obtained analytically; therefore, it is difficult to evaluate from the nutritional point of view which will be the ideal limit among these differences. Probably, a variation of up to $20 \%$ in the consumption of nutrients by healthy individuals is acceptable. However, for those who need to control a specific nutrient intake due to some diseases, for example, this variation can represent an important risk factor.

Currently, the need for reliable and updated food composition data has been continuously growing since nutrition is a major modifiable determinant of chronic diseases, and scientific evidence has increasingly supported the view that changes in diet have strong effects, both positive and negative, on health throughout life (GNAGNARELLA et al., 2004). It should also be pointed out that nutritional labeling, besides representing an important instrument in the context of healthy diet promotion, is compulsory. Therefore, faithful and clear information should be widely available and strictly regulated (LOBANCO et al., 2009; FERREIRA; LANFER-MARQUEZ, 2007; SCAGLIUSI; MACHADO; TORRES, 2005).

\section{Conclusions}

Among the twenty-one biscuits analyzed, sixteen were not in compliance with Brazilian legislation in relation to fat, protein, 
total fiber, calcium, and sodium contents. In at least one specific analysis of each product, the difference between the results and the values described on the label was greater than the legally allowed limit (20\%). The differences in fat and sodium content found are worrisome since the excessive consumption of these nutrients can be harmful to health. The differences between the sodium content found in the present study confirm that the total amount of sodium consumed could be underestimated, mainly when it is based on information described on industrialized products' labels. It is essential to clarify the importance of food and nutrients for health and the nutrition information labeling on foods, especially to avoid excessive consumption of high energy dense foods. The results obtained in the present study indicate the constant need for FCDBs' quality improvement in order to avoid nutrient consumption estimate mistakes, both for individuals and the population.

\section{Acknowledgments}

The authors are grateful for the financial support provided by Fundação Carlos Chagas Filho de Amparo à Pesquisa do Estado do Rio de Janeiro - FAPERJ.

\section{References}

ASSOCIATION OF OFFICIAL ANALYTICAL CHEMISTS - AOAC. Official Methods of Analysis of the Association of Official Analytical Chemists . 18th ed. Gaithersburg: AOAC, 2005.

BRASIL. Ministério da Saúde. Agência Nacional de Vigilância Sanitária. Normas técnicas especiais - Alimentos enriquecidos. Portaria no 27 , de 13 de janeiro de 1998. Aprova o Regulamento Técnico referente à Informação Nutricional Complementar (declarações relacionadas ao conteúdo de nutrientes), constantes do anexo desta Portaria. Diário Oficial da República Federativa do Brasil, Brasília, DF, 16 jan. 1998. Disponível em: <http://www.anvisa.gov.br>. Acesso em: 16 mar. 2011.

BRASIL. Ministério da Saúde. Agência Nacional de Vigilância Sanitária. Resolução RDC no 360, de 23 de dezembro de 2003. Regulamento Técnico sobre Rotulagem Nutricional de Alimentos Embalados. Diário Oficial da República Federativa do Brasil, Brasília, DF, dez. 2003. Disponível em: <http://www.anvisa.gov.br>. Acesso em: 11 mar. 2011.

BRASIL. Ministério da Saúde. Análise da Estratégia Global para Alimentação Saudável, Atividade Física e Saúde. Brasília, 2004. Documento realizado pelo Grupo técnico assessor instituído pela Portaria do Ministério da Saúde n. 596, de 8 de abril de 2004. Disponível em: <http://portal.saude.gov.br/portal/arquivos/ pdf/4artigo_analise_global.pdf>. Acesso em: 16 mar. 2011.

BRASIL. Ministério da Saúde. Agência Nacional de Vigilância Sanitária. Resolução RDC n² 269, de 22 de setembro de 2005. Regulamento Técnico sobre a Ingestão Diária Recomendada (IDR) de Proteína, Vitaminas e Minerais. Diário Oficial da República Federativa do Brasil, Brasília, DF, set. 2005. Disponível em: <http://www.anvisa. gov.br>. Acesso em: 16 mar. 2011.

CAMPOS-VEGA, R.; LOARCA-PINA, G.; OOMAH, B. D. Minor components of pulses and their potential impact on human health. Food Research International, v. 43, n. 2, p. 461-482, 2010. http:// dx.doi.org/10.1016/j.foodres.2009.09.004

CHAMPAGNE, C. M.; LASTOR, K. C. Sodium intake: Challenges for researchers attempting to assess consumption relative to health risks.
Journal of Food Composition and Analysis, v. 22, p. S19-S22, 2009. http://dx.doi.org/10.1016/j.jfca.2009.01.009

CONFORTI, P. A.; LUPANO, C. E. Functional properties of biscuits with whey protein concentrate and honey. International Journal of Food Science \& Technology, v. 39, n. 7, p. 745-753, 2004. http:// dx.doi.org/10.1111/j.1365-2621.2004.00838.x

COZZOLINO, S. M. F. Deficiência de Minerais. Estudos Avançados, v. 21 , n. 60 , p. $119-126,2007$. http://dx.doi.org/10.1590/S010340142007000200009

DIB, M. W.; RIERA, R.; FERRAZ, M. B. Estimated annual cost of arterial hypertension treatment in Brazil. Revista Panamericana de Salud Pública, v. 27, n. 2, p. 125-131, 2010. PMid:20339616. http:// dx.doi.org/10.1590/S1020-49892010000200006

DUNBAR, G. Task-based nutrition labelling. Appetite, v. 55, n. 3, p. 431-435, 2010. PMid:20692310. http://dx.doi.org/10.1016/j. appet.2010.07.016

FERRARI, C. C.; SOARES, L. M. V. Concentrações de sódio em bebidas carbonatadas nacionais. Ciência e Tecnologia de Alimentos, v. 23 , n. 3, p. 414-417, 2003. http://dx.doi.org/10.1590/S010120612003000300021

FERREIRA, A. B.; LANFER-MARQUEZ, U. M. Legislação brasileira referente à rotulagem nutricional de alimentos. Revista de Nutrição, v. 20, n. 1, p. 83-93, 2007. http://dx.doi.org/10.1590/ S1415-52732007000100009

FERREIRA, K. S.; GOMES, J. C.; CHAVES, J. B. P. Cooper content of commonly consumed food in Brazil. Food Chemistry, v. 92, n. 1, p. 29-32, 2005. http://dx.doi.org/10.1016/j.foodchem.2004.07.004

GAETKE, L. M.; CHOW, C. K. Copper toxicity, oxidative stress, and antioxidant nutrients. Toxicology, v. 189, n. 1-2, p. 147-163, 2003. http://dx.doi.org/10.1016/S0300-483X(03)00159-8

GNAGNARELLA, P. et al. The update of the Italian Food Composition Database. Journal of Food Composition and Analysis, v. 17, p. 509-522, 2004. http://dx.doi.org/10.1016/j.jfca.2004.02.009

GRIMES, C. A.; RIDDELL, L. J.; NOWSON, C. A. Consumer knowledge and attitudes to salt intake and labelled salt information. Appetite, v. 53, p. 189-194, 2009. PMid:19540891. http://dx.doi. org/10.1016/j.appet.2009.06.007

HSU, P.-K.; LIN, K.-M.; CHAU, C.-F. Esterification of insoluble fibres using high-pressure homogenisation and their potential vitamin carrying and releasing abilities. Food Chemistry, v. 113, n. 4, p. 1015-1019, 2009. http://dx.doi.org/10.1016/j. foodchem.2008.08.054

ISKEN, F. et al. Effects of long-term soluble vs. insoluble dietary fiber intake on high-fat diet-induced obesity in C57BL/6J mice. The Journal of Nutritional Biochemistry, v. 21, n. 4, p. 278-284, 2010. PMid:19369060. http://dx.doi.org/10.1016/j.jnutbio.2008.12.012

JODRAL-SEGADO, A. M. et al. Magnesium and calcium contents in foods from SE Spain: influencing factors and estimation of daily dietary intakes. The Science of the Total Environment, v. 312 , n. $1-3$, p. $47-58,2003$. http://dx.doi.org/10.1016/S00489697(03)00199-2

JONES, D. B. Factors for converting percentages of nitrogen in foods and feeds into percentage of protein. Washington: United States of Department of Agriculture, 1941. n. 183, p. 1-22. Disponível em: <http://www.nal.usda.gov/fnic/foodcomp/Data/Classics/cir183. pdf $>$. Acesso em: 15 jul. 2010.

KUS, M. M. M. et al. Informação nutricional de fórmulas infantis comercializadas no Estado de São Paulo: avaliação dos teores de lipídeos e ácidos graxos. Revista de Nutrição, 
v. 24 , n. 2 , p. $209-218,2011$. http://dx.doi.org/10.1590/S141552732011000200002

LEE, Y. et al. Analytical dietary fiber database for the Nacional Health and Nutrition Survey in Korea. Journal of Food Composition and Analysis, v. 21, n. 1, p. S35-S42, 2008. http://dx.doi.org/10.1016/j. jfca.2007.07.008

LEVY-COSTA, R. B. et al. Disponibilidade domiciliar de alimentos no Brasil: distribuição e evolução (1974-2003). Revista Saúde Pública, v. 39, n. 4, p. 530-540, 2005. PMid:16113900. http://dx.doi. org/10.1590/S0034-89102005000400003

LOBANCO, C. M. et al. Fidedignidade de rótulos de alimentos comercializados no município de São Paulo, SP. Revista Saúde Pública, v. 43, n. 3, p. 499-505, 2009. PMid:19347174. http://dx.doi. org/10.1590/S0034-89102009005000020

MARTIN C. A. et al. Trans fatty acid content in Brazilian biscuits. Food Chemistry, v. 93, p. 445-448, 2005. http://dx.doi.org/10.1016/j. foodchem.2004.10.022

MENEZES, E. W.; GIUNTINI, E. B.; LAJOLO, F. M. A questão da variabilidade e qualidade de dados de composição de alimentos. Nutrire, v. 26, p. 63-76, 2003.

MENEZES, E. W. et al. New information on carbohydrates in the Brazilian Food Composition Databases. Journal of Food Composition and Analysis. v. 22, n. 5, p. 446-452, 2009. http:// dx.doi.org/10.1016/j.jfca.2009.02.001

MOHSEN, S. M. et al. Effect of substitution of soy protein isolate on aroma volatiles, chemical composition and sensory quality of wheat cookies. International Journal of Food Science \& Technology, v. 44, n. 9, p. 1705-1712, 2009. http://dx.doi.org/10.1111/j.13652621.2009.01978.x

OLIVARES, M. et al. Iron, zinc and copper: contents in common Chilean foods and daily intakes in Santiago, Chile. Nutrition, v. 20, n. 2, p. 205-212, 2004. PMid:14962688. http://dx.doi.org/10.1016/j. nut.2003.11.021

PAREYT, B. et al. The role of sugar and fat in sugar-snap cookies: Structural and textural properties. Journal of Food Engineering, v. 90, p. 400-408, 2009. http://dx.doi.org/10.1016/j. jfoodeng.2008.07.010

PENNINGTON, J. A. T. Applications of food composition data: Data sources and considerations for use. Journal of Food Composition and Analysis, v. 21, n. 1, p. S3-S12, 2008. http://dx.doi.org/10.1016/j. jfca.2007.02.005

PEREGO, P. et al. Effects of changes in ingredient composition on the rheological properties of a biscuit industry dough. International Journal of Food Science and Technology, v. 42 , n. 6, p. 649-657, 2007. http://dx.doi.org/10.1111/j.13652621.2006.01330.x

PROSKY, L. et al. Determination of insoluble and soluble dietary in foods and food products. Journal of the Association of the Association of Official Analytical Chemists International, v. 75, n. 2, p. 360-367, 1992.
RAMÍREZ-CÁRDENAS, L. et al. Zinc bioavailability in different beans as affected by cultivar type and cooking conditions. Food Research International, v. 43, n. 2, p. 573-581, 2010. http://dx.doi. org/10.1016/j.foodres.2009.07.023

RODRIGUES, M. A. et al. Desenvolvimento de formulações de biscoitos tipo cookie contendo café. Ciência e Tecnologia Alimentos, v. 27, n. 1, p. 162-169, 2007. http://dx.doi.org/10.1590/ S0101-20612007000100029

SAMPAIO, R. M. et al. Moisture adsorption behavior of biscuits formulated using wheat, oatmeal and passion fruit flour. Journal of Food Processing and Preservation, v. 33, n. 1, p. 105-113, 2009. http://dx.doi.org/10.1111/j.1745-4549.2008.00276.x

SOCIEDADE BRASILEIRA DE CARDIOLOGIA - SBC. V Diretrizes brasileiras de hipertensão arterial. 2003. Disponível em: $<\mathrm{http}: / /$ www.publicacoes.cardiol.br/consenso/2006/VDiretriz-HA.asp. Acesso em: 23 mar. 2011.

SCAGLIUSI, F. B.; MACHADO, F. M. S.; TORRES, E. A. F. S. Marketing aplicado à indústria de alimentos. Nutrire. v. 30, p. 79-95, 2005. Disponível em: <http://www.sban.com.br/educacao/nutrire/30/ nut30_6.htm>. Acesso em: 14 jul. 2010.

SHERMAN, A. R.; MEHTA, O. Potassium in food additives: something else to consider. Journal of Renal Nutrition, v. 19, n. 6, p. 441-442, 2009. PMid:19818297. http://dx.doi.org/10.1053/j. jrn.2009.08.010

SHILS, M. E. et al. Tratado de Nutrição Moderna na Saúde e na Doença. 9. ed. São Paulo: Manole, 2003. 171 p. PMid:14652109.

SICHERT-HELLERT, W. et al. German food composition database for dietary evaluations in children and adolescents. Journal of Food Composition and Analysis, v. 20, p. 63-70, 2007. http://dx.doi. org/10.1016/j.jfca.2006.05.004

TAVELLA M. et al. Trans fatty acid content of a selection of foods in Argentina. Food Chemistry, v. 69, p. 209-213, 2000. http://dx.doi. org/10.1016/S0308-8146(99)00257-5

TEIXEIRA, M. H.; VEIGA, G. V.; SICHIERI, R. Consumo de gordura e hipercolesterolemia em uma amostra probabilística de estudantes de Niterói, Rio de Janeiro. Arquivos Brasileiros de Endocrinologia \& Metabologia, v. 51, p. 65-71, 2007. PMid:17435857. http://dx.doi. org/10.1590/S0004-27302007000100011

THEUWISSEN, E.; MENSINK, R. P. Water-soluble dietary fibers and cardiovascular disease. Physiology \& Behavior, v. 94, n. 2, p. 285-292, 2008. PMid:18302966. http://dx.doi.org/10.1016/j. physbeh.2008.01.001

TYAGI, S. K. et al. Effect of mustard flour incorporation on nutritional, textural and organoleptic characteristics of biscuits. Journal of Food Engineering, v. 80, n. 4, p. 1043-1050, 2007. http://dx.doi. org/10.1016/j.jfoodeng.2006.08.016

TOSH, S. M.; YADA, S. Dietary fibres in pulse seeds and fractions: Characterization, functional attributes, and applications. Food Research International, v. 43, p. 450-460, 2010. http://dx.doi. org/10.1016/j.foodres.2009.09.005 